\title{
Carolyn Richmond, Días felices. Aproximaciones a El jardín de las delicias de Francisco Ayala, Sevilla, Fundación José Manuel Lara, 2018, 268 pp.
}

\author{
Irma Emiliozzi \\ Universidad Nacional de Lomas de Zamora, Argentina
}

Cita sugerida: Emiliozzi, I. (2019). [Revisión del libro Días felices. Aproximaciones a El jardín de las delicias de Francisco Ayala por C. Richmond]. Olivar, 20(31), e079. https://doi.org/10.24215/18524478e079

Con esta aproximación no sólo al Jardín de las delicias de Francisco Ayala sino e inevitablemente, como veremos, a la totalidad de su obra, Carolyn Richmond confirma su envergadura de gran conocedora del universo ayaliano. Conocedora más que investigadora ya que su mirada contiene y trasciende su extensa labor de investigación sobre el autor para sumar su privilegiado punto de vista como lectora, como mujer de Francisco Ayala, inseparable compañera de sus trabajos y sus días y actual Presidenta de honor de la pujante Fundación Francisco Ayala de Granada.

Richmond despliega, en principio y como uno de sus ejes dominantes, el carácter de verdadero work in progress en que consistió la gestación de El jardín de las delicias a lo largo de una cincuentena de años, desde 1971 a 2006, fecha de su edición definitiva, por lo que este título se constituirá como un libro abierto que irá creciendo, cambiando, madurando como la vida misma.

E inmediatamente insistirá en la problemática Del mezzo del cammin dantesco, la problemática del "después" del texto, y no sólo para el eventual lector o receptor del libro sino para el mismo autor transformado también él en un receptor. ¿¿ aún para alguien más?

Luego del puzzle narrativo que despliega, Richmond se ocupará de observar cómo el fragmento, la parte, el trozo, es la técnica predominante del libro. Y frente a este caleidoscopio, a estos "trozos de un espejo roto", apuntalará como otro gran hilo conductor la visión poliédrica del mundo, desde un marcado perspectivismo cervantino. 
Y aún, como si este panal de incontables celdas no se terminara, le faltará todavía detenerse en el elemento gráfico del libro, en la cantidad de imágenes, paneles, ilustraciones que se añaden al segmentado corpus verbal y que también se alterará, se modificará con el correr de los años. El autor apela así a los cincos sentidos de su lector.

Desde el personalísimo preámbulo "Mi Jardín de las delicias", seguido por una "Introducción. Un clásico moderno (Pasajes)", y por dos partes constitutivas del núcleo de este estudio (la primera es "Proyecciones", formada por 1. Galería de espejos. 2. Templo de reflejos. 3. Realidad y ensueño. 4. Experiencia e invención); y la segunda, "Una historia", formada por el frondoso punto 5: "De mis pasos en la tierra", y hasta el final de "Días felices. Aproximación a El jardín de las delicias", la autora irá diseccionando, separando, distinguiendo con el fin de alcanzar el todo. Lo que podríamos llamar la mirada analítica de Richmond, se completará con una "Relación de obras de Francisco Ayala citadas" y un Apéndice: "Contenido textual de cinco ediciones de El jardin de las delicias".

A modo de epílogo, Francisco Ayala cierra El jardin de las delicias, ya en su primera edición, con una enigmática página fechada en Chicago el 28 de abril de 1971. A sus sesenta y cinco años se asoma el autor al "después": ¿continuará el viaje de la vida, o no? Como en toda despedida, ahora al despedirse de su libro, aparecerán las preguntas angustiosas, instalado el autor en el cammin que es el tiempo, y que adelanta el tema del más allá o la vida eterna (la cursiva es de C. Richmond) y el del más acá del destino final del libro. ¿O hay otras despedidas? El cierre de esta página posee un tono más íntimo, más piadoso o solidario y hasta tierno o amoroso pues incluye no sólo al mismo autor ya lector, a los lectores que en el camino de la vida se asomarán a estas páginas, sino a una "prudente" destinataria.

Es que esta lectura de Richmond, y también en actitud dialogante o abierta como el mismo Ayala usó al escribir El jardín de las delicias, no deja de apelarnos, de alejarnos del texto primario en cuestión. Y asistiremos también a la descripción de la composición de este libro, de la génesis y devenir de este texto "secundario" o lector del "primario".

Cuenta Richmond que desde el comienzo de la escritura de esta "aproximación”, al finalizar su tarea diaria Ayala se acercaba a su escritorio, también en actitud abierta y dialogante. La muerte del escritor dejó a la autora, su lectora y compañera, durante largo tiempo a la deriva, que finalmente concluyó con su firme decisión de concluir este libro que hoy tenemos entre las manos. De esta manera, otro verdadero work in progress se despliega ante nosotros, otro viaje u "odisea intelectual” como lo califica la autora (¿sólo intelectual...?).

Nos apartamos así del estudio analítico original para desembarcar en esta personalísima obra en marcha, superpuesta, abarcadora de la anterior, ahora la de la autora Carolyn Richmond. Con esta estructura de "rulo" o "tirabuzón", permanentemente entrelazado, entremezclado pero enseguida libre, escapando al volver las páginas de El jardín de las delicias, Richmond invita a "sus" lectores también a seguirla con "actitud inquisitiva, abierta y participativa”.

Y todos somos "cómplices" de este sucederse de recortes, diálogos y evocaciones líricas del "arca de palabras" que es El jardín de las delicias desde la perspectiva de Carolyn Richmond, y lo somos de su personalísimo recorrido, de este recorrido fiel, enamorado (de "Carta de amor" habla Luis García Montero). "Una vez que hube empezado no pude parar", nos confiesa la autora acerca de la etapa de finalización de esta "Aproximación”, con lo que desnuda la aventura total de su lectura, de su recepción, de la explícita derivación del texto primario en este segundo texto. Este libro se ha cerrado y la autora alcanza a asomarse, invitada en diálogo fecundo por Ayala desde el "epílogo" de El jardín de las delicias a su liberación al fin. También ahora a la nuestra.

Con este texto, Richmond se aleja de lo que tradicionalmente llamamos crítica literaria para instalarse en el creativo dominio del ensayo, de lo confesional, de la experiencia y la invención: quizás, y entre otros, es el valor del libro que más me interesa destacar. 